\title{
REVOKING EARLY CONDITIONAL RELEASE MEASURES IN SPAIN
}

\author{
José Cid \\ Criminologia Aplicada a la Penologia \\ Department of Political Science and Public Law \\ Universitat Autònoma de Barcelona \\ e-mail: Josep.Cid@uab.es
}

\section{Beatriz Tébar}

Departament d'Interior

Generalitat de Catalunya

The final, definitive version of this paper has been published in European Journal of Probation, 4 (1): 112-124, 2012, by SAGE Publishing.

Available at http://dx.doi.org/10.1177/206622031200400110 


\begin{abstract}
$^{1}$
In this article we examine how early conditional release measures for offenders are revocated in Spain. For this purpose we analyse the legal framework of revocation, paying special attention to the criteria and the procedures legally established. We also take a look to the practice of revocation by showing the figures the case law on this subject. Finally, the most critical issues on revocation are outlined according an approach based on the philosophical that should rule revocation and the constitutional principles that inform conditional early release mechanisms.
\end{abstract}

Keywords: early conditional release recalling, prison allocation, parole.

\footnotetext{
${ }^{1}$ This research has been funded by the Spanish Ministry of Science and Innovation (Políticas de reinserción en el ámbito penal, DER 2008-0541) and the Catalan Government (AGAUR Grupo de Investigación consolidado en Criminología aplicada a laPenología, SGR 2009-1117). The data presented in this paper has been provided by Ramon Pares, Director of the Catalan Prison System and Virgilio Valero, Director of Rehabilitation of the Spanish Prison). We would like to thank especially the prison judge Benito Pérez, one of the six prison judges in Catalonia, for a long interview with him that improved very much our understanding of the practice of revocation of conditional early release measure. We also want to thank Mireia Balaguer, Manuel Cachón and Carme Navarro for the time they devote to answer our questions. Nicky Padfield was not only the person who came out with this project on comparative penology but also challenged us with stimulating questions that we have tried to answer. Beatriz Tébar would also like to thank the Catalan Government for the Batista i Roca scholarship she was granted to conduct comparative research on parole at the Institute of Criminology of the University of Cambridge from March to December 2003.
} 
INTRODUCTION: AN OVERVIEW OF THE SPANISH EARLY RELEASE SYSTEM (Cid and Tébar 2010a).

Spanish law provides two ways to be early conditional released while serving a prison sentence: open-regime (with include home detention curfew) and conditional liberty or parole.

Both mechanisms are categories or classifications from the Spanish prison system set by the General Penitentiary Act 1979. This Act introduced a progressive system based on individualisation of the prison regime, which provides the following four main levels of classification or treatment categories as they are named by the General Penitentiary Act 1979, where the higher the level is the more open is the prison regime implemented:

\begin{tabular}{|l|l|}
\hline \multicolumn{2}{|c|}{ THE SPANISH PRISON SYSTEM } \\
\hline Prison Treatment Categories & Prison Regime \\
\hline 1st category & Closed or max security regime. \\
\hline 2nd category & Ordinary regime \\
\hline $3^{\text {rd }}$ category & Open regime or home detention curfew \\
\hline 4th category & Parole \\
\hline
\end{tabular}

\section{Open Regime and Home detention curfew}

Third degree prison regime or category is a kind of semi-detention whereby prisoners spend the day outside prison, usually working, and return to prison only at nights, from Monday to Thursday. While from Friday to Sunday third degree prisoners normally benefit from a weekend leave. 
Third degree classification is a prison measure regulated mainly by the 1979 General Penitentiary Act and the 1996 Prison rules, although some provisions about this regime where introduce by the 7/2003 Fundamental Law, which reformed the Spanish Criminal Code.

As for the legal criteria to be categorised as a third degree prisoner, two ways are foreseen. First, prisoners may be first classified in an open regime if they have a good risk prognosis. However the Prison Administration only decides an initial third degree classification in the case of first-time prisoners with short sentences and a very good risk prognosis (Capdevila et. al. 2006). Secondly, the third level may be reached as a progression from the second prison category. The 1996 Prison Rules provide this classification in the third category once a quarter of the sentence has been served and provided the prisoner is considered to be ready for resettlement. Despite these legal criteria, the Prison Administration practice requires the following additional criteria to receive a third degree allocation: having served half of the sentence; having previously been granted temporary leave from prison; and having a remaining sentence that would make them eligible for ordinary parole in no more than two or three years (Cid 2005; López-Ferrer 2004). In both case, as a primary classification and as a progression from the second level, Spanish Criminal Code section 36, requires prisoners to pay the civil liability arouse form the offence committed decided in the sentence or at least to make guarantees of payment according to their possibilities. Another legal requirement established by the s.36 Criminal Code relating to classification into the third level refers to the discretional power of the sentencing Judge to imposed a minimum mandatory period of half of the sentence before classification in the third period, when a sentence 
longer than five years is being served. This minimum mandatory period can be lifted by the prison judge, provided that a low risk of reoffending is predicted. For sentences longer than five years imposed for offences related to terrorism, organised crime, sexual offences against victims under thirteen the minimum mandatory period before reaching the third treatment category is perceptive and cannot be judicially lifted afterwards.

As for release in home detention curfew, prisoners allocated to the third level who carry out labour or treatment activities outside the establishment, are eligible to be released by this means during the nights. The 1996 Prison Rules established this special regime that allows third level prisoners to replace the nightly return to prison by a home detention curfew, so they only have to visit prison for arranged interviews with their supervision agent. Generally, the home detention period, which normally lasts from $11 \mathrm{pm}$ to $7 \mathrm{am}$, is monitored by electronic tagging or by police officers.

\section{Parole}

Parole allows sentenced prisoners to be released into the community with supervision before the end of a prison sentence. Supervision implies observing certain rules or conditions, among which it is always included a duty not to re-offend. Parole remains in force until the sentence expiry date, unless it is revoked earlier and the offender is recalled to prison. As explained below, different modalities of parole can be distinguished according to the criteria required to be released. Mention also should be made to some cases where the type of prisoner, the number of offences committed and 
the length of the prison terms involved can lead to a prison sentence without parole as provided by section 78 of the Criminal Code 2 .

\section{(i) Ordinary parole}

Ordinarily, parole can be granted from the three quarter point of the sentence and provided that the offender meets the requirements of a third level classification, good behaviour and a good prognosis, which includes the duty to comply with any of the civil liabilities, arose by the offence. In this latter sense, fully restitution is not required but a willingness to compensate the victim in relation to the offender's means.

\section{(ii) Earlier parole}

The time for release on parole can be advanced to two thirds or even half the sentence if additional requirements relating to participation in treatment and continuous labour activities are met. There are no clear legal or judicial criteria to distinguish between the use of ordinary and advance parole. The Prison Judiciary body Agreements (2009) that earlier parole and in particular parole at $1 / 2$ of the sentence should be considered for exceptional cases and this is reflected in the statistics that show that getting parole at $1 / 2$ of the sentence occurs very scarcely (see statistics in Cid and Tébar 2010a).

\section{(iii) Humanitarian Parole}

A special parole regime is provided for humanitarian reasons, for those who are 70 or more years old and for those who suffer for an incurable illness. In these cases parole can be granted at any stage of the sentence, provided that the other criteria are met. The

\footnotetext{
${ }^{2}$ On the Spanish legal framework see generally Vega (2001), Renart (2003), Tébar (2006a) and Cid and Tébar (2010a).
} 
Spanish Constitutional Court has considered ${ }^{3}$ that this type of parole is grounded on the fundamental right of life and human dignity so it can only be denied on the basis of a high risk for the public protection.

(iv) Parole for prisoners convicted of terrorism and offences related to organised crime There are stricter parole rules for prisoners convicted of terrorism and offences related to organised crime. Such offenders are additionally required to repudiate their criminal activities and apologise to their victims. They can only be paroled after they have served three quarters of their sentences, since they are legally excluded from any advanced form of parole. In addition, if a the time of the conviction they are banned from parole or the minimum time required to be conditionally released is extended, as a result of implementing section 78 of the Criminal Code, and afterwards the prison Judge decides to raise such a measure, in any case they can only access parole during the last eighth part of their sentence.

\section{REVOCATION OF OPEN REGIME}

\section{Legal Framework and Practice}

Revocation of open regime -or "regression" as the Spanish Penitentiary law calls itmeans that the prisoner placed in an open facility that develops part of the day-life into the community, is allocated in a closed regime, where the entire time is spend inside the prison. Moreover, the regression implies the restriction of the right of leaves during the weekend, which is part of the open regime system. Regression clearly implies an end in the process of early release in the community.

\footnotetext{
${ }^{3}$ Constitutional Court decision 48/1996, 25th March 1996. www.tribunalcontitucional.es
} 
The Penitentiary Act has only one rule about the grounds of revocation of open regime. Article 65.3 of this Act states: "Regression [to a close regime] must be established when, in relation to treatment, the personality of the prisoner evolves negatively". The lack of specific rules to regulate revocation can be explained by the absence of a written statement with the rules or conditions that must be obeyed during the open regime. The prisoner is informed of the obligations attached to the open regime by means of the scheduled encounters with an early release office.

The lack of rules with respect to revocation gives to the authorities competent to make decisions on regression a great deal of discretion on what behaviours or attitudes of the prisoner should be considered as a "negative evolution of her personality with respect to treatment". A review or the few cases that have arrived to the high court in the last five years $(2005-2010)^{4}$ shows that some examples of grounds of revocation are the following: being accused of a new offence, being arrested by the police for a new offence, a positive test of drug consumption, leaving the therapeutic facility in the community, losing the work in the community, losing the confidence of the early release officers on her commitment to rehabilitation.

A complete vision of the grounds for revocation would require a field work with a sample of prison files, but an analysis of the published case law from 2005 to 2010 shows that the list of possible reasons for revocation is rather large and it points out that

\footnotetext{
4 Audiencia Provincial Islas Baleares (sección 1a). Auto 367/2006, 29-06-2006 (JUR 2006/191672); Audiencia Provincial Barcelona (sección 21). Auto 866/2009, 12-06-2009 (JUR 2009/464944); Audiencia Provincial Ciudad Real (sección 2a). Auto 2/2008, 28-01-2008 (JUR 2008/167890); Audiencia Provincial Cádiz (sección 1a). Auto 160/2010,30-06-2010 (JUR 2010/349698); Audiencia Provincial Madrid (sección 5a). Auto 3007/2009, 8-10-2009 (JUR 2010/20965); Audiencia Provincial Islas Baleares (sección $1^{a}$ ). Auto 38/2007, 9-02-2007 (JUR 2007/126912); Audiencia Provincial Cádiz (sección $1^{\text {a }}$ ). Auto 309/2008, 31 -10-2009 (JUR 2009/202866). Audiencia Provincial Madrid (sección 5a). Auto 2440/2006, 30-05-2006 (JUR 2006/230322); Audiencia Provincial Murcia (sección 5 ). Auto 252/2009, 29-09-2009 (JUR 2009/460456); Audiencia Provincial Barcelona (sección 21). Auto 938/2009, 29-06.2009 (JUR 2009/465873). All the decisions may be accessed through the data-base: www.westlaw.es
} 
Spanish system of revocation of open regime is problematic on the subject or legal guarantees of prisoners.

\subsection{Procedure of revocation}

The procedure to revoke and open regime and recall a person to a closed prison regime is based on the following features:

(i) Following an informal report of the early-release officer that manages the case of a specific prisoner, the Treatment Board, the formal body of the prison system that takes over the rehabilitation process, writes a statement proposing the revocation of the open regime for a prisoner. This statement contains the reasons for the proposal of revocation.

(ii) The general director of the prison system $^{5}$ decides on the proposal of the Treatment Board. This decision must state the reasons for recalling and the right to challenge it before the prison judge. Once communicated to the prisoner, the decision of revocation is immediately enforced. In case that the prisoner is outside the prison he would receive a call informing about the recall and the obligation to an urgent return to prison. Only after this procedure fails, the prison judge is informed in order to emit an order of search to be enforced by the police ${ }^{6}$.

(iii) The prisoner has the right to appeal the decision to the prison judge. In order to make the written appeal the prisoner has the right to be assisted by a lawyer but at his own expense or on a voluntary basis, since no legal right of free legal advice is granted

\footnotetext{
5 Direcció General de Serveis Penitenciaris i Rehabilitació (Catalonia) and Secretaria General de Servicios Penitenciarios (rest of Spain).

${ }^{6}$ The procedure to communicate a recall to a prisoner is not written in the law, neither in the prison judge association agreements (2009), but it seems to be a practice of the prison judges (Prison Judge Benito Pérez, personal communication).
} 
at this stage of the process $)^{7}$. The parts in the procedure are the prisoner and the public prosecutor $^{8}$. Neither the law, nor the decisions of the prison judiciary body agreements (Jueces de Vigilancia Penitenciaria, 2009) establish the right of the prisoner to have an oral hearing in front of the prison judge in order to present reasons against the revocation. In case the prisoner asks during the procedure to see the prison judge to explain his arguments against the recall, the judge has the discretion to accept or refuse the interview (Prison Judge Benito Pérez, personal communication). At the own expense prisoner, a contradictor report may be presented before the prison judge, in order to sustain the prisoner's view against revocation of open regime, but the prison judge rarely counts with a professional that could prepare another report that the judge may contrast with the one elaborated by the prison treatment body (Jueces de Vigilancia Penitenciaria, 2009).

(iv) The decision of the prison judge with respect to the revocation of open regime may be further appealed to the magistrate or to the court that sentenced the offender. The appeal may be sustained by the prisoner and by the public prosecutor. In this appeal the prisoner should be assisted by a lawyer and free-legal aid for poor offenders is provided.

\section{Data on revocation of open regime}

Before presenting data on revocation of open regime it should be reminded that in the Spanish penitentiary system, early release is not the most common way to be release to the community (see Cid and Tébar 2010a). Data of Catalonia indicates that in the last 5 years (2006-2010) 37\% were release on open regime (including home detention curfew)

\footnotetext{
${ }^{7}$ The prison judiciary body agreements ask for a legal reform given the prisoner the right of free legal aid at least in some cases (Jueces de Vigilancia Penitenciaira, 2009, decision 151). For a justification of this claim among Spanish scholars: Navarro (2002).

${ }^{8}$ In some places, it may exist a public prosecutor that is specialized in prison cases.
} 
and on parole and $63 \%$ were release from closed regime, without any period or conditional early release. Data of the rest of Spain is not officially provided but on the basis of extrapolation of data it could deduced that the percentage of prisoners that get early release is similar to Catalonia (Cid and Tébar 2010b).

Figure 1. Form of release. Catalonia (2006-2010) (average)

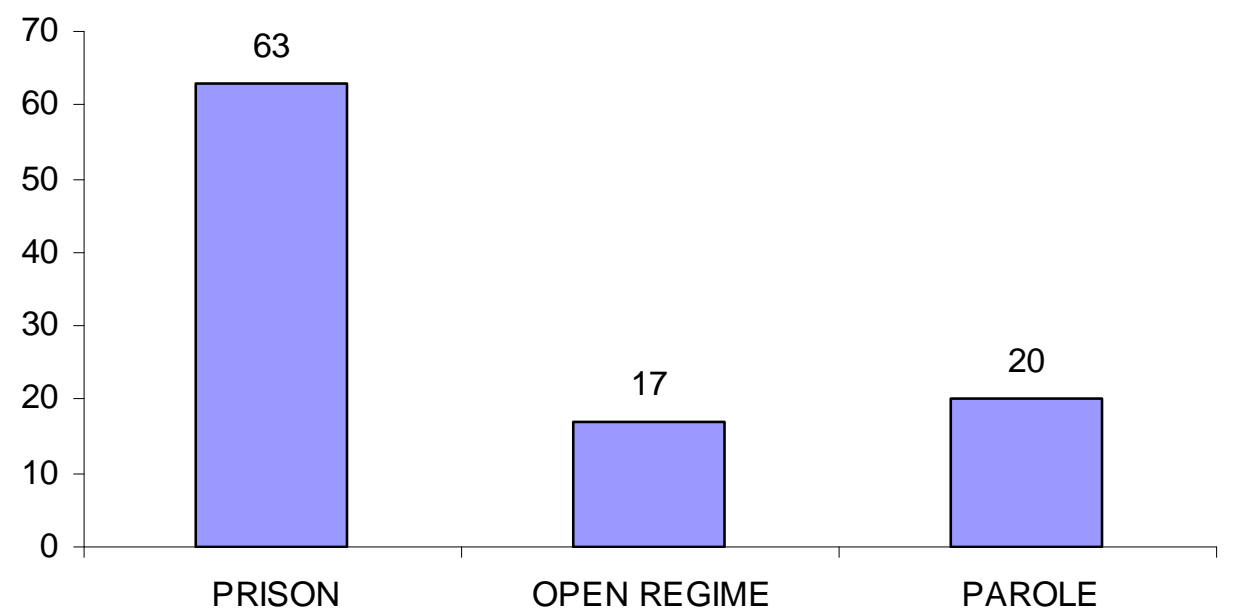

Source: Data not published, provided to the authors from: Direcció General de Serveis Penitenciaris (Catalonia) (July 2011). www.gencat.cat/justicia

What is the role of revocation of open regime in the fact that less that half of prisoners are early released? Before trying to answer to this question we should explore the possible reasons for these low rates. One possible reason relates with the fact that a proportion of prisoners do not start a process of early release (a process that start with leaves and continue with open regime). Research done by one of the authors indicate that this category includes basically: prisoners serving short prison sentences (for the time that takes the process of classification), prisoners that have served a relevant part of the sentence as a remand prisoners (that excludes the possibilities of classification) and prisoners with high levels of misbehaviour in prison (being good conduct a legal 
requirement for being granted the early release mechanisms) (Tébar 2006b). The second possible reason relates with prisoners that have started a process of early release but this process has been interrupted. Data on the use of revocation of open regime in Spain (Catalonia and the rest of Spain) for the last 5 years (2006-2010) indicates that a relevant proportion of the prisoners that get open regime are recalled to prison and probably for most of this prisoners revocation implies that they don't get a second open regime and finish they sentence without any conditional release in the community.

Table 1. Revocation open regime. Spain $(2006-2010)^{9}$

\begin{tabular}{|l|l|l|l|l|l|l|l|l|l|}
\hline & \multicolumn{3}{|l|}{ CATALONIA } & \multicolumn{3}{l|}{ REST OF SPAIN } & \multicolumn{2}{l|}{ SPAIN } \\
\hline $\begin{array}{l}\text { Year } \\
\text { Open } \\
\text { regime } \\
\text { granted }\end{array}$ & $\begin{array}{l}\text { Open } \\
\text { regime } \\
\text { revoked }\end{array}$ & $\begin{array}{l}\text { open } \\
\text { regime } \\
\text { revoked }\end{array}$ & $\begin{array}{l}\text { Open } \\
\text { regime } \\
\text { granted }\end{array}$ & $\begin{array}{l}\text { Open } \\
\text { regime } \\
\text { revoked }\end{array}$ & $\begin{array}{l}\% \text { open } \\
\text { regime } \\
\text { revoked }\end{array}$ & $\begin{array}{l}\text { Open } \\
\text { regime } \\
\text { granted }\end{array}$ & $\begin{array}{l}\text { Open } \\
\text { regime } \\
\text { revoked }\end{array}$ & $\begin{array}{l}\% \text { open } \\
\text { regime } \\
\text { revoked }\end{array}$ \\
\hline $\mathbf{2 0 0 6}$ & 1644 & 576 & 35.0 & 7991 & 1076 & 13.5 & 9635 & 1652 & 17.1 \\
\hline $\mathbf{2 0 0 7}$ & 1525 & 562 & 36.9 & 8600 & 1318 & 15.3 & 10125 & 1880 & 18.6 \\
\hline $\mathbf{2 0 0 8}$ & 1695 & 518 & 30.6 & 8606 & 1718 & 20.0 & 10301 & 2236 & 21.7 \\
\hline $\mathbf{2 0 0 9}$ & 1820 & 499 & 27.4 & 10980 & 1622 & 14.8 & 12800 & 2121 & 16.6 \\
\hline $\mathbf{2 0 1 0}$ & 1989 & 488 & 24.5 & 12674 & 1708 & 13.5 & 14663 & 2196 & 15.0 \\
\hline $\mathbf{2 0 0 6 -}$ & & & & & & & & & \\
$\mathbf{2 0 1 0}$ & & & 30.9 & & & 15.4 & & & 18.1 \\
\hline
\end{tabular}

Sources: Catalonia: http://www.gencat.cat/justicia/estadistiques_serveis_penitenciaris/

Rest of Spain: Information provided to the authors by: Mr. Virgilio Valero García. Director General de Coordinación y Medio Abierto. Secretaria General de Instituciones Penitenciarias (Ministerio del Interior) (June 2011).

\footnotetext{
${ }^{9}$ The Basic explanation for the differences rates of revocation between Catalonia and the rest of Spain are due to the fact that in Catalonia the time that the prisoner should serve in open regime before getting parole is higher than in the rest of Spain. Less time in open regime implies less possibilities of revocation. To explore further this subject : Cid (2005), Cid and Tébar (2010a).
} 


\section{3- REVOKING EARLY CONDITIONAL RELEASE}

\subsection{Legal Criteria and Practice}

Parole revocation means returning to a second category prison regime, while a new classification is decided by the prison Treatment Board, as provided by section 201.3 of the 1996 Prison Rules. Generally the initial classification after a recall from parole would be the second category ${ }^{10}$. The time spent in liberty before revocation counts toward the sentence, except in the case of parolees serving a sentence for a terrorist offence.

As for the grounds for revocation, the Spanish Criminal Code (section 93.1) provides the following two general causes: re-offending and the breach of the license obligations. The Prison Judiciary Body Agreements (2009) also considers that failing to meet the legal criteria to access parole, especially criterions related to having good conduct and holding a positive rehabilitation prognosis, is a cause for parole revocation. This cause of revocation is explicitly established in the case of prisoners sentenced for offences related to terrorism ${ }^{11}$. In respect with humanitarian parole it also should be mentioned that in practice and occasionally a health improvement of the parolee results into a prison recall if a risk of reoffending is assessed.

\section{a)Re-offending}

This cause of revocation is usually construed as committing a crime but not a misdemeanour, according to the Criminal Code provisions and the rule of law (Tébar

\footnotetext{
${ }^{10}$ Personal communication from the Prison Judge Benito Pérez.

${ }^{11}$ As provided by section 93.2 of the Penal Code in these cases the Prison Judge is able to ask reports to proof if the parolee still meets the criteria required to be released during the license period. This way, it can be said that failing to meet the legal criteria required to be released is a specific cause of revocation for terrorist offenders.
} 
2006a). Notwithstanding it must be taken into account that incurring in a misdemeanour can be deemed as a breach of the license conditions, depending on which type of conditions have been impose on the parolee and how they are construed by the Prison Judge.

When re-offending can lead into parole revocation, once the sentence for the new offence is definitive or before, it is not such a pacific question. According to our constitutional mandates regarding the rule of law (sections 9.1 and 25.1) and the presumption of innocence (s. 24), only when there is a final judgment, that is unappealable, re-offending can result into parole revocation. This interpretation frequently implies the impossibility to revoke parole for this cause, since when the eventual penal sentence is definitive, the license period will have expired (SánchezYllera 1996, 523). For this reason the Prison Judiciary Body Agreements (2009) demands a new regulation of revocation that allows recalling before a definitive sentence for a new offence is decided. In practice some Prison Judges decide parole revocation when the offence is flagrant, by means of considering there has been a breach of the license conditions or that the criteria required to access parole is no longer fulfilled. In any case, according to section 93.1 of the Penal Code and the practice, notice to the Prison Judge of a definitive sentence for an offence committed during a license period will automatically lead into parole revocation, regardless the nature of the offence, the circumstances of its commission or if it has any relationship with the former offence.

Another ground for revocation used in practice relates to imprisonment of the parolee for a new or an old offence. Traditionally the case law regarding this matter has been 
oscillating between revocating or suspending parole, insofar early conditional release is obviously incompatible with imprisonment. There are no legal provisions for parole suspension. In fact, it is a solution applied by some Prison Judges in those cases where imprisonment is not due to a definitive sentence for an offence committed during the license period, which would lead to parole revocation, but to other situations such as preventive imprisonment for an old or new offence or a prison sentence for deeds that took place before the early conditional release. Parole suspension in these cases is intended to avoid a decision on revocation that would imply to start over the process to be granted parole once the situation of imprisonment would disappear ${ }^{12}$.

But recently the case law on this matter tends to consider that imprisonment while on parole means the loose of classification in the forth category or parole, which in practice has the same effects as revocation ${ }^{13}$.

\section{B ) Breaching license obligations}

As for conditions that can be attached to the license, section 90.2 of the criminal Code leaves a wide range of obligations that relate to:

- Prohibitions relating weapons, driving and professional licenses.

- Restrictions such as not going to some places or not having any contact with victims and their relatives.

- Obligations to meet the parole officer as scheduled undergo treatment or take training or educative programmes.

\footnotetext{
12 In this sense judicial decissions: Audiencia Provincial Barcelona (sección 9). Auto 24 julio 2006, JUR 2007/12441, Audiencia Provincial Baleares (sección 2a). Auto 99/2005, 24 mayo. JUR 2005/14266, Audiencia Provincial Cantabria (sección 1a). Auto 99/2003, 8 octubre, JUR 2004/56196. On this subject see further Armenta and Rodríguez (2006: 356-357), Tébar (2006a: 207) and the case law they refer.

13 Decissions Audiencia Provincial Madrid (sección 5 ${ }^{\text {a }}$ ). Auto 3043/2009, 7 octubre, JUR 2010/2105, Audiencia Provincial Pontevedra (sección 3ª). Auto 3/2008, 7 mayo, JUR 2009/440504.
} 
- $\quad$ Any other condition decided by the Prison Judge and agreed by the parolee.

There are no explicit legal criteria to assess when a failure to meet the conditions attached to the license can result into revocation. This way there is a great deal of discretion in deciding revocation for this ground. A review of judicial decisions on this subject reveals certain consensus in revoking parole as a measure of last resort and if the breach is "definitive", that is, when a clear will to breach the conditions can be derived from the parolee's behaviour ${ }^{14}$. However contradictory decisions can be found, for instance in a case where revocation was decided because the parolee did not appear to a drug control, despite the treatment report stated that the intervention was successful (Audiencia Provincial Madrid (sección 5a) Auto 2940/2009, 30th September, JUR 2940/2009).

No legal provision is either made to allow the modification of the conditions or the imposition of new one, although it is done in practice ${ }^{15}$ or if a previous warning to the parolee before revoking is mandatory.

\section{The way to revocation}

(i) There is not a specific legal procedure to decide on revocation. The way to recall a parolee will starts with a proposal from the parole service, based on a report of the parole officer (in case of technical violation). A communication from the prison system, in case of revocation for re-offending or from police, when there is a detention may also result into a proposal of revocation. This proposal will state the reasons for revocations as well as other information that would consider relevant for the case.

\footnotetext{
${ }^{14}$ For instance decision from the Audiencia Provincial Sevilla (sección 4a). Auto 4 marzo 2004. Jur 2004/126268.

${ }^{15}$ Personal communication from the Prison Judge, Benito Pérez.
} 
(ii) The prison judge will open a procedure of recall in which it has to ask the public prosecutor to make an opinion in favor or against the revocation. There is no an explicit legal obligation to inform the parolee about a notice against him to revoke parole, so the prison judge may discretionally offer the parolees to expose their reasons against the revocation. The decision of the prison judge (revoking parole, holding parole or modifying its conditions) must be noticed to the parolee. The parolee will be asked to return voluntarily to prison before any enforcement by the police is taken. The parolee must also be informed about the right to appeal. The public prosecutor has also the right to appeal any decision of the prison judge.

(iii) If the convict wants to challenge the prison judge decision before the High Court, the right to free legal advice is granted in case of a lack of economic means. The parts of the procedure are the parolee and the public prosecutor. The procedure is written and no oral hearing is granted by law. Demands to an oral hearing may be asked to the Court that has discretion to accept or refuse. The parolee may present a report sustaining the position to hold parole at his own expense.

\subsection{Data on parole revocation}

As show in table 2, rates of revocation of parole for the last five years (2006-2010) are really low compared with data of revocation of open regime (illustrated in table 1): 
Table 2. Revocation of parole. Spain (2006-2010)

\begin{tabular}{|c|c|c|c|c|c|c|c|c|c|}
\hline & CATAL & NIA & & REST 0 & SPAIN & & SPAIN & & \\
\hline & $\begin{array}{l}\text { N. } \\
\text { paroles } \\
\text { granted }\end{array}$ & $\begin{array}{l}\text { N. } \\
\text { paroles } \\
\text { revoked }\end{array}$ & $\begin{array}{l}\% \\
\text { paroles } \\
\text { revoked }\end{array}$ & $\begin{array}{l}\text { N. } \\
\text { paroles } \\
\text { granted }\end{array}$ & $\begin{array}{l}\text { N. } \\
\text { paroles } \\
\text { revoked }\end{array}$ & $\begin{array}{l}\% \\
\text { paroles } \\
\text { revoked }\end{array}$ & $\begin{array}{l}\text { N. } \\
\text { paroles } \\
\text { granted }\end{array}$ & $\begin{array}{l}\text { N. } \\
\text { paroles } \\
\text { revoked }\end{array}$ & $\begin{array}{l}\% \\
\text { paroles } \\
\text { revoked }\end{array}$ \\
\hline 2006 & 574 & 16 & 2.8 & 5881 & 194 & 3.3 & 6455 & 210 & 3.3 \\
\hline 2007 & 648 & 21 & 3.2 & 6344 & 243 & 3.8 & 6992 & 264 & 3.8 \\
\hline 2008 & 590 & 25 & 4.2 & 6364 & 310 & 4.9 & 6954 & 335 & 4.8 \\
\hline 2009 & 587 & 16 & 2.7 & 8115 & 250 & 3.1 & 8702 & 266 & 3.1 \\
\hline 2010 & 731 & 37 & 5.1 & 9614 & 276 & 2.9 & 10345 & 313 & 3.0 \\
\hline $\begin{array}{l}\text { 2006- } \\
2010\end{array}$ & & & 3.6 & & & 3.6 & & & 3.6 \\
\hline
\end{tabular}

Sources: Catalonia: http://www.gencat.cat/justicia/estadistiques_serveis_penitenciaris/Rest of Spain:

Information provided to the authors by: Mr. Virgilio Valero García. Director General de Coordinación y Medio Abierto. Secretaria General de Instituciones Penitenciarias (Ministerio del Interior) (July 2011).

The reasons that may explain the differences between rates of revocation of open regime (30\% in Catalonia and $18 \%$ in the rest of Spain) and the rates of revocation of parole (3.6 in both jurisdictions), are twofold: on the one hand, parolees may have better prognosis of risk than open prisoners, given that for achieving parole the person need to have spend a relevant period in the community without reoffending (more than one year in Catalonia, according to the research of Tébar 2006b). But on the other hand, it seems plausible that the different system of revocation between open regime and parole (discretional in open regime and restricted to the violation of predetermined requirements in parole) and the fact that for parole some high court decisions have lay 
down the principle of revocation as a last resort should also be relevant to understand the different rates of revocation between open regime and parole.

\section{ASSESSING THE REVOCATION OF EARLY CONDITIONAL RELEASE MECHANISIMS}

In order to assess the strengths and shortcomings of the Spanish system of revocation of open regime and parole we should start exposing the philosophical model we use as a starting point of our comments. We share the idea that open regime and parole are institutions in which two concerns should be most relevant: the concern for humanity accepting that open regime and parole are more humane sanctions than closed prisonand the concern for rehabilitation -that takes into account the interest of society as a whole in preventing recidivism (Tébar 2006a). Moreover, we also should take into account the criminological research on open regime and parole that, although not conclusively, seems to support the idea that at least for high-risk offenders a rehabilitation model of supervision in the community is more effective in preventing recidivism than a release without transition (see Cid and Tébar 2010b and Dunkel et al. 2010 for an overview of research). We also claim that this philosophical model is supported by the Council of Europe recommendations -in particular Recommendation (2003) 22, Conditional release (parole)- and by the 1978 Spanish Constitution. Three principles of the Spanish Constitution should be mentioned: first, the fundamental right to freedom (s. 1 and 17 of the Spanish Constitution) that may be relevant when the penitentiary administration or the judiciary have to decide between closed prison or early release (open regime or parole), given a prima facie reason in favour of early release measures; second, the principle that prison sentences should be aimed at rehabilitation and resettlement (s. 25.2 of Spanish Constitution) that requires to takes into account which measure -closed prison or early release measures- is more able to 
achieve the aim of rehabilitation and third, the principle of legality or rule of law and due process (s. 25.1 and 24 of the Spanish Constitution), that demand that a penal sanction should only be imposed for committing infractions stated by the law and after a procedure with guarantees of defence. This philosophical, constitutional and criminological background is the basis of the main principle that, according to our view, should regulate the whole system of revocation of early release measures: the idea that recalling form early release mechanisms should be a measure of last resort, being only applied when is accredited that the person has violated the conditions of the supervision and there is a clear refusal to accept the conditions proposed to reduce the risk of reoffending (See Cid 2009 for a more detailed explanation of the philosophical grounds in sentencing).

On the basis of the philosophical background mentioned -and in particular in the principle of revocation as a last resort- we formulate the following critical reflections about the Spanish system of early release revocation.

(i) Probably the main critical point of the Spanish system of revocation concerns to the lack of clear criteria to revoke open regime. When a prisoner is classified in open regime the conditions attached to this early release measure are not stated (neither by the law, nor by prison authorities). Lack of clear conditions to follow during open regime means that revocation is completely discretional for the prison administration and it also means that the real possibilities of judicial review, by the prison judge and further by the sentencing judge, are very limited, because discretion can only be submitted to legal control when the task of the judge consist of verifying if the revocation decided by the prison administration is based on the law (Ferrajoli 1989). 
Moreover, lack of clear conditions for open regime means that the system does not meet the ideal of certainty for the open prisoner.

(ii) A second point that deserves attention is the lack of rules to decide what should be considered as a breach of the conditions of supervision. Although there are some decisions of the high court (mainly in relation to parole) stating that in case of infraction of technical rules, revocation should only be adopted when the person refuse to continue with the supervision, the system would require a whole reform on the basis of the principle of revocation as a measure of last resort. The main principles of this reform should be: a) in case of a procedure for infraction of technical rules of supervision, the breach should not be considered as a single infraction of rules but a refusal to the earlyreleased prisoner or parolee to continue with the conditions of supervision (that may be modified to prevent new technical violations); b) in case of a procedure for a newoffence, when the offender is not imprisoned for the new offence, the prison judge should have the possibility of holding the prisoner in early release when the new offence is not serious and provided the early released prisoner accepted the new conditions of supervision.

(iii) A third point concerns the procedure to revoke open regime and parole. In this aspect the Spanish system meets the constitutional requirements with respect to the right to judicial review. However, there are two main shortcomings: on the one hand, the lack of rights of the prisoner to participate in the hearing. It is true that prison judges have the discretion to grant to early release convicts the possibility of exposing their reasons against revocation, but the right to an oral hearing should be granted by law. The second drawback refers to the lack of probation officers at disposal of the prison judge to make 
reports that may help to take decisions, especially in cases in which the judge may have doubts about the reports of the prison administration.

(iv) Our final point is related to the research on desistance that one of the authors is doing at present (Cid and Martí 2011). In this qualitative research, we have observed that after an interruption of the process of early release, the motivation of the prisoner to start again a process of change is hard to achieve and most convicts that have been recalled to prison finish their sentences in ordinary regime and are released to society with any kind of supervision. This outcome is not only negative in respect with humanitarian grounds but also attending to public safety considerations. Finally the present status quo raises the importance of back sentencing as a concern for scholars and patricians (Padfield and Maruna 2006).

\section{REFERENCES}

Armenta, F.J; Rodríguez, V. (2006). Reglamento penitenciario comentado, $5^{\text {a }}$ edición Sevilla: Editorial Mad.

Capdevila, M. et al. (2006). La classificació inicial en règim obert dels condemnats a presó, (http://www20.gencat.cat/portal/site/Justicia), (as consulted of $28^{\text {th }}$ February 2009).

Cid, J. (2005). The Penitentiary System in Spain. The Use of Imprisonment, Living Conditions and Rehabilitation. Punishment and Society, 7:2, 147-66

Cid, J. (2009). La elección del castigo. Suspensión de la pena o probation versus prisión. Barcelona: Bosch. 
Cid, J and Martí, J. (2011). El proceso de desistimiento de las personas encarceladas. Obstáculos y apoyos. Barcelona: Centro de Estudios Jurídicos y Formación Especializada.

http://www20.gencat.cat/docs/Justicia/Documents/ARXIUS/SC_3_175_11_cast.pdf

Cid, J.; Tébar, B. (2010). Spain. N. Padfield, D. Van Zyl Smit i F. Dünkel (eds.). Release from prison. European policy and practice. Cullompton: Willan, 358-392.

Cid, J; Tébar, B. (2010b). Libertad condicional y delincuentes de alto riesgo. Revista Española de Investigación criminológica, $\quad 8 / 3, \quad 1-23$. http://www.criminologia.net/pdf/reic/ano8-2010/a82010art3.pdf

Dunkel, F; van Zyl Smit, D.; Padfield, N. (2010). Concluding thoughts. N. Padfield, D.; Van Zyl Smit; F. Dünkel (eds.). Release from prison. European Policy and Practice. Cullompton: Willan, 358-392.

Ferrajoli, L. (1989). Diritto e ragione. Teoria del garantismo penale. Roma-Bari: Laterza.

Jueces de Vigilancia Penitenciaria (2009). Criterios de actuación, conclusiones y acuerdos aprobados por los jueces de vigilancia penitenciaria en sus XVIII reuniones celebradas entre 1981 y 2009 (Texto refundido y depurado actualizado a junio de 2009 (ed. de F. Bueno Arús). Madrid: Consejo General del Poder judicial http://www2.scjn.gob.mx/seminario/docs/Art-2.pdf (as consulted the 11th October 2011) López-Ferrer, M. (2004). Cárceles abiertas. Unpublished PhD dissertation, Universitat Autónoma Barcelona.

Padfield, N.; Maruna, S. (2006).The revolving door at the prison gate: exploring the dramatic increase in recalls to prison. Criminology and Criminal Justice, 6, 329-352. 
Navarro, C. (2002). La ejecución de la pena privativa de libertad: garantías procesales. Barcelona: J. M. Bosch.

Sanchez-Yllera, I., (1996). artículos 90-93, en Tomás S. Vives Antón (coordinador), Comentarios al Código penal de 1995, Vol I, Valencia: Tirant lo Blanch, 511-524.

Renart, F. (2003). La libertad condicional: nuevo régimen jurídico, Madrid: Edisofer, Tébar, B. (2006a). El modelo de libertad condicional español, Pamplona: Aranzadi.

Tébar, B. (2006b). La aplicación de la libertad condicional en España. Revista de Derecho Penal y Criminología 19, 283-315.

Vega, M. (2001). La libertad condicional en el derecho español, Madrid: Cívitas. 